\title{
BEST PARENTING-PARENTS TO DIET AND FOOD-CONSUMPTION ON TODDLERS
}

\author{
(Pola Asuh Orang Tua Terbaik untuk Pola Makan dan Konsumsi Makanan pada Balita)
}

\author{
Heri Bahtiar, Maelina Ariyanti, Aswati \\ STIKES YARSI Mataram \\ TGH Ali Batu Lingkar Selatan Street - Kodya Mataram \\ E-mail: heribahtiar_76@yahoo.com
}

\begin{abstract}
ABSTRAK
Pendahuluan. Sebanyak 103 anak di Kabupaten Lombok Barat menderita gizi buruk sepanjang 2013 sebanyak 646 anak. Kabupaten Lombok Barat menempati posisi kedua dari 10 Kabupaten/Kota di NTB yang terbanyak penderita gizi buruk. Hal ini disebabkan oleh penyakit dan pola asuh orang tua yang belum bagus. Tujuan dari penelitian ini adalah menganalisis hubungan pola asuh orang tua dengan pola makan dan konsumsi makanan pada balita. Metode. Metode penelitian menggunakan observasional analitik dengan Cross-sectional design. Populasi seluruh rumah tangga yang mempunyai balita yang ada di Desa Banyu Urip, teknik simple random sampling, jumlah sampel 81 balita. Analisa data menggunakan Spearman Rank. Hasil. Pola asuh orang tua terbanyak dalam kategori otoriter 47 (58\%), pola makan balita dalam kategori cukup baik 58 (71,6\%), konsumsi makanan pada balita dalam kategori difisit $27(33,3 \%)$. Tidak ada hubungan pola asuh orang tua dengan pola makan $(\mathrm{p}=0,095)$ dan konsumsi makanan balita $(\mathrm{p}=0,17)$. Diskusi. Pola asuh terbaik untuk pola makan dan konsumsi makanan bagi balita gizi kurang dan Gizi buruk adalah pola asuh otoriter.
\end{abstract}

Kata kunci: Pola asuh, Pola makan, Konsumsi makanan, Balita

\section{ABSTRACT}

Introduction. There are 103 toddlers in West Lombok suffering from severe malnutrition throughout 2013. This regency is ranked as the second place out of ten districts/cities in NTB having severely malnourished. It is due to the fact that illness and parenting-parents have yet been considered. The purpose of this study was to analyze relationship parenting-parent with diet and toddlers food consumption. Method. This study used analytical observation research with Cross-sectional design. The population were the entire households having children at Banyu Urip village with the samples, eighty-one toddlers, were taken through random sampling technique. Its data was analyzed by using Spearman Rank. Result. The finding shows; 1) parenting-parents, most authoritarian, is 47 (58\%); 2) diet toddler, good category, is 58 (71.6\%); 3) food-consumption on toddlers, deficit category, is 27 (33.3\%); 4) no relationship among the parenting-parents, diet ( $p=$ $0.095)$ and toddler food consumption $(p=0.17)$. Discussion. Thus, it can be inferred that an authoritarian-parenting is the best parenting to diet and food-consumption for toddler-malnutrition.

Key words: Parenting, Diet, Food-consumption, Toddler

\section{INTRODUCTION}

Nutritional status is the third-indicator in determining the children health status in Indonesia. Nutritional problem is a public health problem which can be encountered neither through medical approaches nor health services (Suparisa, 2012).

NTB Provincial Health Department released 103 children in West Lombok experiencing malnourished throughout 2013 (out of 646 toddlers-malnutrition in NTB, December 2013). West Lombok regency is ranked as the second place out of 10 districts/ cities in NTB having severely malnourished. It is due to the fact that illness and parenting- parents have yet been considered (Lombok Post, April 11, 2014, Page 18). It is found that, from 2011 to 2013, there are twenty-seven poor-nutrition-toddlers and seven malnutrition in Banyu Urip village Gerung Sub-district West Lombok - NTB (PHO Lobar 2013).

One of the breakthroughs made by the government is to improve child nutrition through improving the infant feeding and child (PMBA). However this could not be run as smoothly as expected. Food-consumption affects the personal nutritional status. Good nutritional status occurs when the body is getting enough nutrients used efficiently and poor nutritional status occurs when the body 
has a deficiency of one or more essential nutrients (Almatsier, 2009).

The incidence of malnutrition is also caused by the parents who are too busy with their own daily activities. Those make them pay less attention to their toddler mealtime and diet (Savitri, 2008). Based on the explanation above, the researcher is interested in conducting research on what type of the best parentingparents to diet and food-consumption for toddlers in Banyu Urip village - Gerung Subdistrict West Lombok.

\section{METHODS}

This study used analytical observational study with a cross sectional design. The population was the 102 households having children in the aged of two to five years old in Banyu Urip village West Lombok district. The sample was a half of the households.
Independent variable of this study was parenting parents and the dependent variable is the toddler diet and energy consumption. Questionnaires were used as an instrument of parenting and diet and Open-sheet was used for food consumption. Data were analyzed using Spearman rank.

\section{RESULT}

Toddlers, as respondents, are classified into gender, age, father's education, mother's education, parents' occupation. In terms of age, there $35(43.2 \%)$ are infants, and $46(56.8 \%)$ are the pre-school age infants. In terms of education level, most of the mothers, 28 people $(34.6 \%)$ are junior high school level, and the fractions were Elementary and uneducated. In addition, in terms of occupation, most of them, fifty-nine people (72.8\%) are housewives and around two people $(2.5 \%)$ are farmers.

Table 1. Frequency of distribution of toddler- parenting-parents in Banyu Urip village Gerung District of West Lombok

\begin{tabular}{clcc}
\hline No & \multicolumn{1}{c}{ Parenting } & Frequency & \% \\
\hline 1 & Authoritariany & 47 & 58 \\
2 & Democrative & 31 & 38,3 \\
3 & Permissive & 3 & 3,7 \\
\hline Total & & 81 & 100 \\
\hline
\end{tabular}

Table 2. Frequency Distribution of Toddler-Diet in Banyu Urip Village Gerung District of West Lombok

\begin{tabular}{clccc}
\hline No & & Diet & Frequency & \% \\
\hline 1 & Poor & & 10 & 12,3 \\
2 & Fair & 58 & 71,6 \\
3 & Good & 13 & 16 \\
\hline Total & & 81 & 100 \\
\hline
\end{tabular}

Table 3. Frequency Distribution of Food-Consumption in Banyu Urip Village Gerung District of West Lombok

\begin{tabular}{clcc}
\hline No & Food-Consumption & Frequency & \% \\
\hline 1 & Deficit & 27 & 33,3 \\
2 & Poor & 18 & 22,2 \\
3 & Average & 17 & 21 \\
\hline Total & & 62 & 100 \\
\hline
\end{tabular}


Best Parenting-parents to Diet and Food-consumption on Toddlers (Heri Bahtiar, dkk.)

Table 4. Relationship between Parenting and Diet in Banyu Urip Village

\begin{tabular}{lcccc}
\hline \multirow{2}{*}{ Parenting } & \multicolumn{5}{c}{ Diet } & N \\
\cline { 2 - 5 } & Poor & Fair & Good & 47 \\
Authotitarian & 7 & 33 & 7 & 31 \\
Democrative & 3 & 23 & 5 & 3 \\
Permissive & 0 & 2 & 1 & 81 \\
N & 10 & 58 & 13 & \\
\hline \multicolumn{7}{c}{ Spearman-rank $\mathrm{p}=0,095$} \\
\hline
\end{tabular}

Table 5. Relationship between Parenting and Food-Consumption in Banyu Urip Village

\begin{tabular}{lcccc}
\hline \multirow{2}{*}{ Parenting } & \multicolumn{3}{c}{ Diet } & N \\
\cline { 2 - 5 } & Deficit & Fair & Average & 47 \\
Authotitarian & 19 & 10 & 8 & 31 \\
Democrative & 8 & 7 & 8 & 3 \\
Permissive & 0 & 1 & 1 & 81 \\
N & 27 & 18 & 17 & \\
\hline \multicolumn{5}{c}{ Spearman-rank $\mathrm{p}=0,170$} \\
\hline
\end{tabular}

Table 2 showed that most respondents have a fair diet $(71,6 \%)$ and $12,3 \%$ respondents have a poor diet. Most parents, 47 respondents (58\%), are authoritarian parenting and around 3 respondents $(3.7 \%)$ are permissive. Table 3 showed that 27 respondent of the toddlers $(33.3 \%)$ were deficit, and at least 17 toddlers (21\%) have the average diet. Table 4 show that there was no relationship between parenting and diet $(\mathrm{p}=0,095)$.

Authoritarian parenting-parents were those who mostly have toddler food consumption in the deficit category or viceversa. Therefore, there was no a positive relationship between parenting and food consumption.

\section{DISCUSSION}

\section{Parenting-parents}

Most parents, about 58\%, have authoritarian parenting and about $3.7 \%$ have permissive parenting. Parenting is the attitude of parents to interact with their children. It includes on how parents should provide rules and attention. Parenting as a treatment of the elderly in order to meet needs, provide protection and to educate children in their daily life. Moreover, parenting-parents, on children, is a form of interaction between children and parents during the care which means parents need to educate, guide and protect their child (Gunarsa, 2002).

Another factor playing an important role in parenting is parents' occupation. The data show that parents of the toddlers have a diverse occupation. Most of their work is housewives. Parents' occupation is a source of income for the family fulfilling needs of physical, psychological and spiritual. If parents have a steady job, the family welfare has also increased and the role of parenting can be done well.

Family, a basis place for a childdevelopment, is the foremost environment in a child-life. It takes an appropriate parenting so that children grow and develop optimally. Self-image is always associated with the development of the child based parenting. Infants generally prefer choosing food denseenergy. Parents are often disappointed with children because they choose the food that they prefer than the food which has more nutritious. If the mother was bored with the children eating problems, they will be indifferent in their child nutrition need. Unlike the parents as authoritarian or democratic, they will always force the child to eat foods that are essential to the growth and development. It is due to the 
fact that the school age is a period in which the child grew and developed very rapidly.

\section{Toddler Diet}

Most parents, around $71.6 \%$, have a pretty good parenting and the least, $12.3 \%$, have a diet lacking. Children have a unique diet in terms of type, time and taste. This uniqueness can sometimes make a nanny confused. The nanny often gives away to the child to eat without trying to figure out the cause of the child's difficult to eat. Alternatively, s/he, sometimes, gives the desired food to calm the child regardless of the nutritional content of the food. While the infancy is a period of rapid growth and development, thus, the needs for high nutrients must be fulfilled. Nutritious food functions; 1) optimizes the processes of growth and development; 2.) Maintains health and restore health when sick; 3) performs various activities.

\section{Food-consumption}

Most toddler, $33.3 \%$, are categorize as the deficit food consumption, while $21 \%$ is the fraction. Carbohydrates are one of the energy-producing foods, such as grains or cereals such as rice, corn, and wheat; tubers such as yams, cassava and taro; and processed products such as starch, noodles, vermicelli, macaroni, bread, and havermuot. Based on the Nutritional Adequacy Rate (NAD), the energy consumption in the age of 1 to 3 years as much as $1000 \mathrm{kcal}$, whereas in the age of 4 to 5 years as much as $1550 \mathrm{kcal}$. Protein is a macro nutrient functioning as a builder substance and energy. NAD for protein intake of children aged 1-3 years as much as 25 grams and 4-5 years as much as 39 grams. Consumption of diverse foods will prevent nutrient deficiencies because the composition of nutrients in food complements each other. It aims to obtain a balanced nutrient input. Children the ages of 1 to 5 years can also be said to have begun after breast feeding until weaning or pre-school. In accordance with the growth and development of intelligence agencies, his physiology is also experiencing growth so that the type of food and method of administration must be adjusted to the situation.

\section{Relationship between Parenting and Diet}

Parents applying more authoritarian parenting toddlers have a pretty good diet. The statistical test between parenting and diet values was obtained that significant level $(\mathrm{p})=$ 0.095 where $p>0.05$, which means that $\mathrm{H} 0$ is failed to be rejected. Thus, it can be concluded that there is a positive relationship between the parenting parents and the diet. Diet for a child needs to be done properly because children are different from adults.

Children are human figures that are changing and the rapid development in the next life, the development of; digestion system, organs, brain, and soul. It is not only about how the fulfillment of the proper amount of nutrients and the physical of food, but also on how to give them. If the daily food consumption is less diverse, there will be an imbalance between intake and nutrient requirements necessary for a healthy and productive life. By eating a daily diet of diverse, the lack of nutrients in foods will be complemented. Hence, in order to obtain a balanced intake of nutrients, we need to provide the diverse foodstuffs (Banudi, 2013).

\section{Relationship between Parenting and Food- Consumption}

The majority of parents, having authoritarian parenting, have toddler food consumption levels in the deficit category, but most of them have also good. The statistical test between parenting and food-consumption was obtained that significant level $(p)=0.170$ where $\mathrm{p}>0.05$, which means that $\mathrm{H} 0$ is failed to be rejected. Thus, it can be concluded that there is no a positive relationship between the parenting parents and food-consumption. Thing often leading to malnutrition in children under five is the incompatibility of the amount of nutrients that they get from food with their body's needs. Another thing is about the children-food preferences having less of nutrients. 
Parenting-practices are a fairly strong determinant of the nutritional status of children, though the children come from poor families. It is also proved by Moehji, that malnutrition is not only found in families earning less but also in relatively good income families.

At age 1 year, toddlers tend to be hard to eat and consume food in small portions. According Almatsier, et al (2011), children tend to have the frequency of eating more than three meals a day, this is because the size of a small toddler stomach, so feed five to six times a day is better than three times a day. However, the frequency of eating is apparently unrelated to nutrient intake. According Almatsier, et al. (2011), Parents are often concerned about the refusal of children to nutritious food, or to impose limits on the intake of food, or about the child's behavior towards food. It is highly suggested to avoid feeding when children are not too hungry and give attention when children eat, give praise when children spend a portion of their food.

\section{CONCLUSION}

Authoritarian-parenting is the best parenting to diet and food-consumption for toddler-malnutrition

\section{RECOMMENDATION}

Malnutrition on children can be overcome if parenting in the toddler diet and food-consumption (protein-energy) should use authoritarian parenting.

\section{REFERENCES}

Almatsier, Sunita. (2009). Prinsip Dasar Ilmu Gizi. Gramedia Pustaka Utama: Jakarta

Almatsier, Sunita, S. Soetardjo, dan M. Soekarti. (2011). Gizi Seimbang dalam Daur Kehidupan. PT Gramedia Pustaka Utama: Jakarta

Banudi,La. (2013). Gizi kesehatan reproduksi. Jakarta: EGC.

Dinas Kesehatan Lombok barat (2013). Profil Kesehatan kabupaten Lombok barat. Dinkes Lobar

Dinas Kesehatan Provinsi Nusa Tenggara Barat. (2013). Profil Kesehatan Provinsi Nusa Tenggara Barat Tahun 2012. Mataram

Gunarsa dalam Vina Nurrahmatin Permasih (2014) Hubungan pola asuh orang tua dengan temperamen pada remaja di smk kesatrian purwokerto, skripsi Universitas jenderal soedirman Fakultas kedokteran dan ilmu - ilmu kesehatan Jurusan keperawatan Purwokerto

Suparisa, dkk. (2012) Penilaian Status Gizi. Jakarta: EGC

Savitri. (2008). Kebutuhan Nutrisi dan Tumbuh Kembang Anak, Jakarta: Rineka Cipta 